\title{
Ruínas Modernistas, Arqueologias Fílmicas: A Free and Anonymous Monument, de Jane e Louise Wilson ${ }^{1}$ Giuliana Bruno ${ }^{2}$
}

Artista e arquiteto falam a mesma língua... O ambiente urbano é uma paisagem artificial, de tal modo que o processo de o construir não é diferente de uma composição pictórica que manipulamos de forma imaginativa; ao longo da estrada, pelo caminho, através das árvores, ao virar da esquina, do outro lado do monte... O espaço é uma função do sentimento.

Victor Pasmore

Entramos no espaço. Está lá um remanescente arquitetónico. Enquadra o espaço, literal e metaforicamente, dando-lhe perspetiva. Tudo o que existe é a geometria mental da obra. Tudo o que nos resta fazer é rendermo-nos. Deste modo, entramos nesta grande estrutura, sentindo uma superfície tectónica de betão. A estrutura revela ser uma entrada e torna-se num corredor introdutório. Existe uma longa parede suspensa sobre as nossas cabeças que nos guia para dentro de um espaço. Caminhamos ao longo desta estrutura, deixando-nos guiar, como que preparando-nos para uma visita guiada.

Avançamos no nosso ritmo para outras formas de remanescentes arquitetónicos. As paredes que agora olhamos movem-se. $\mathrm{Na}$ verdade, são feitas de imagens em movimento. São paredes de luz e ecrãs de movimento. Os treze diferentes planos de projeção, criando duas câmaras de visão, estão orientados em direções opostas. Dissociados, chegam-nos de diferentes ângulos, estão refletidos no chão, e até pairam sobre nós. Nas superfícies inclinadas dos ecrãs posicionados de diferentes modos, vemos uma verdadeira profusão de imagens. São projetadas simultaneamente, em todas as paredes-ecrãs, de todos os ângulos de visão. Imagens em sítios industriais e pósindustriais são projetadas em loop, e ficamos hipnotizados, enquanto vemos estes planos de luz explodindo em imagens. Andamos, paramos, olhamos e voltamos a andar, e começamos a ficar completamente imersos nesta multifacetada geografia visual. O espaço toma conta de nós, visceralmente, pela força da sua construção audiovisual. Ao sair, encontramos outra estrutura de betão suspensa

\footnotetext{
${ }^{1}$ Tradução do texto originalmente publicado em Bruno, Giuliana. 2007. "Modernist Ruins, Filmic Archaeologies. Jane and Louise Wilson's A Free and Anonymous Monument." In Public Intimacy: Architecture and the Visual Arts, 43-86. Cambridge: MIT Press.

${ }^{2}$ Harvard University, Department of Visual and Environmental Studies, Quincy Street, Cambridge, MA 02138, USA.
} 
que, funcionando como um corredor, se torna um suporte para a instalação.

Em algum ponto da sua crescente complexidade, por baixo da imaculada superfície, sentimos um cansaço material, a força de uma lânguida visão. Em última análise, do lugar emana uma persistente sensação de melancolia. Este espaço caleidoscópico parece assombrado por uma memória. É como se o próprio espaço fosse uma lembrança, falando de algum lugar que também nós conhecemos intimamente.

\section{Um Monumental "Cenário" 3 de Imagens}

A Free and Anonymous Monument (2003), a instalação multi-ecrã de imagem-movimento de Jane e Louise Wilson, parece um elaborado cenário. Enquanto cenário, é um espaço vivido, frequentado pelas histórias que ali aconteceram ao longo do tempo, contendo vestígios dessas narrativas espaciais. O primeiro conjunto destas memórias está inscrito na superfície das paredes, na própria arquitetura que enquadra o espaço da instalação, fornecendo tanto entrada como saída. As sugestivas arquiteturas de betão que descrevemos como estando à entrada e à saída são, de facto, substitutos para a construção do passado. São, na verdade, remanescentes - vestígios do Pavilhão Apollo construído em 1958 pelo artista Victor Pasmore em Peterlee New Town, perto de Newcastle. As paredes suspensas são, literalmente, memórias suspensas.

À medida que acedemos às duas câmaras criadas pelos ecrãs sem suporte, também elas começam a parecer suspensas no espaço. Sem uma moldura, elas não parecem pictóricas mas antes espaço arquitetónico. Construídos de uma forma aberta ao espaço em redor, os ecrãs evocam uma construção suspensa que o próprio Pasmore fez com Richard Hamilton em 1956 para uma exposição de "Environmental Painting” na Galeria Hatton, em Newcastle. Apropriadamente intitulada An Exhibit, era uma pintura ambiental através da qual o visitante, tornado espectador, podia caminhar.

Seguindo o caminho trilhado por Pasmore, Jane e Louise Wilson projetaram a sua própria visita guiada ambiental. A sua viagem arquitetónica, uma memória reconstruída da visão espacial de Pasmore, é uma construção - uma construção mnemónica que assombra completamente o espaço de A Free and Anonymous Monument. Mas é quando ficamos imersos nas câmaras da instalação, a olhar para os diferentes tipos de paredes - as superfícies que são ecrãs - que ficamos literalmente dentro do espaço da memória de Pasmore. Entre outras imagens, os ecrãs projetam cenas do Pavilhão Apollo. Este bastião utópico da renovação e regeneração urbanas, agora abandonado, é mostrado no seu atual uso como um lugar de recreio para os jovens

\footnotetext{
${ }^{3}$ No original, set tem para a autora o duplo sentido de 'grupo' e ‘cenário' (N.T.).
} 
locais. O seu uso lúdico remonta-nos para a ideia do que era um pavilhão na sua função arquitetónica original. De fato, vários vestígios da memória estão inscritos na forma do pavilhão e cabe-nos a nós, visitantes, desvendar a sua história.

\section{O Tecido da Memória: O Fantasma de Victor Pasmore}

Se aqui a memória é realmente tecida, ela também é habitada, e Pasmore é o principal habitante desta arquitetura mnemónica. Ele é o fantasma do lugar, pois aqui o pavilhão não é apenas o objeto de retrato, mas um elemento formal da representação, a chave para aceder à sua visão.

A lembrança dos planos visuais de Pasmore assombra A Free and Anonymous Monument em diversas camadas - ou planos - do passado. Num primeiro nível, mostra como o próprio Pasmore exibe um vestígio do passado no modo como projetou a sua visão artística. Abandonando um primeiro interesse em pintura paisagista, o artista aproximou-se da arte abstrata e do design urbano, acabando depois por remontar a um momento anterior. Ao elaborar a sua ideia do modernismo no pós-guerra, virou-se para os cânones do modernismo na Europa anterior à guerra, revivendo e reinterpretando as visões racionais, formas abstratas, passeios arquitetónicos ${ }^{4}$, e sonhos utópicos da sua fase anterior num esforço, segundo ele, de estabelecer "um alfabeto de sensações visuais em forma abstrata" (Pasmore in Bowness 1980, 14).

Em 1955, Pasmore foi convidado pelo diretor geral da Peterlee Development Corporation para colaborar com os arquitetos na execução do planeamento urbano de frações de uma nova cidade perto de Newcastle, então em construção. Esteve mais de vinte anos envolvido neste processo, até 1977. Nas mãos de Pasmore, a forma de relevo abstrato que, na altura, caracterizava a sua arte tornou-se a grelha de uma arquitetura. Segundo ele, tinha chegado o momento em que era "capaz de construir um relevo abstrato à escala de uma cidade. O relevo torna-se num ambiente arquitetónico de grande complexidade que, tal como o interior de um edifício, é vivido por dentro; como tal, acolhe uma qualidade subjetiva que é implicitamente multi-dimensional" (Pasmore in Bowness 1980, 15).

Textura abstrata e movimento foram unidos na obra de Pasmore, pois, como um relevo concebido no meio ambiente, o esboço das secções da cidade foi pensado de um modo dinâmico. A conceção espacial presente na arte de Pasmore facilmente migrou para este planeamento urbano, pois tanto a arte como o planeamento urbano foram pensados em conjunto, como práticas do espaço. Como tal, ambos foram sintonizados com os modos experienciais de receção, e

\footnotetext{
${ }^{4}$ No original: architectural promenades, a partir do conceito de Le Corbusier promenade architecturale (N.T.).
} 
houve o cuidado de incluir na própria conceção aqueles que iriam usufruir do espaço. Na verdade, para ver a obra de arte de Pasmore o visitante tinha de se mover de modo a captar as mudanças subtis que ocorriam na luz e cor das formas projetadas. Podemos inclusive dizer que tal visitante, tornado espectador, poderia acionar a obra de arte. Um fazedor de obras de arte que pedem ao visitante que se mova de modo a experienciá-las rapidamente iria abraçar o planeamento de uma cidade - que é, também, uma questão de movimento no espaço. De facto, como Le Corbusier notou de forma exemplar na sua noção de "passeios arquitetónicos", a arquitetura "é apreciada enquanto está em movimento, com os pés... enquanto se caminha, movendo-nos de um sítio para outro... Um verdadeiro passeio arquitetónico [permite] constantes mudanças de pontos de vista, inesperados, por vezes surpreendentes" (Le Corbusier 1964, 24) . $^{5}$.

Seguindo a trajetória da arquitetura modernista, Pasmore reinventou a arquitetura do pós-guerra como uma prática que implica ver de uma forma peripatética. E assim, o movimento espacial que tinha caraterizado as suas pinturas e relevos transformou-se em movimento urbano. O projeto de uma nova cidade tornou-se a verdadeira extensão da inovadora e móvel visão artística do espaço em Pasmore.

\section{Seguindo e Superando o Caminho de Pasmore}

Um pintor paisagista desenvolve um sentido de forma e espaço enquanto experiência móvel - uma condição essencial do planeamento urbano, e na verdade de toda a arquitetura.

Victor Pasmore

O percurso de Victor Pasmore tem sido influente. Através da sua arte e das suas obras de design, bem como do seu extenso envolvimento na educação, ele desbravou um caminho na arte britânica que tem sido seguido por muitos e que é agora repavimentado por A Free and Anonymous Monument, de Jane e Louise Wilson'. A sua homenagem a Pasmore é, de facto, fiel à obra que referencia: aqui, ver é uma atividade; olhar é caminhar. À medida que os espetadores percorrem o espaço da instalação e se envolvem na apresentação visual, eles acionam a obra. A sua presença e a articulação física do seu movimento desenham o espaço artístico.

Ao percorrer a instalação das Wilson, ouvimos ecos subtis do design móvel que Pasmore queria para a sua própria "Exposição". Quase que o podemos ouvir dizer:

\footnotetext{
${ }^{5}$ Le Corbusier desenvolve a ideia de passeio arquitetónico ao ler o itinerário da Villa Savoye (1929-1931) relativamente ao movimento na arquitetura árabe.

${ }^{6}$ Sobre a arte britânica do pós-guerra, ver Robbins 1990.
} 
Imagino que estou a andar ou a conduzir nas ruas retiradas do meu desenho. É um processo cinético. À medida que caminhamos ali, que viramos aqui, através de uma pequena passagem além, para um espaço aberto aqui, encontramos um edifício alto ali, um frontão aqui, um conjunto de casas além" (Pasmore 1980, 261).

$\mathrm{Na}$ instalação das Wilson, o espaço é encontrado justamente desta maneira, pois a própria posição dos ecrãs de projeção é pensada cineticamente. Aqui, não são apenas as imagens que se movem: também a imagem de arquitetura o faz. As direções divergentes destes ecrãs falam de um plano artístico ele próprio concebido em movimento, e o projeto da instalação proporciona mais do que caminhos para se andar: ele cria uma arquitetura móvel visual. De tal modo em movimento ${ }^{7}$, Jane e Louise Wilson não se limitaram a referenciar o itinerário artístico e o método de design de Pasmore. Na verdade, elas redesenharam-no.

Neste processo de redesenhar um espaço móvel visual, as Wilson vão além de Pasmore ao estabelecerem a mobilidade do processo de design. Tal é particularmente verdade em relação à conceção do espetador da obra de arte. Se o visitante de Pasmore, impelido a mover-se, se tornava espetador, aqui o visitante é literalmente um espetador - um espetador de cinema. O passeio arquitetónico redesenhado pelas irmãs Wilson não é apenas cinético mas verdadeiramente cinemático. Nesta instalação, não há contemplação estática, uma vez que o visitante fica envolvido num projeto audiovisual totalmente mobilizado - uma montagem móvel fílmicoarquitetónica.

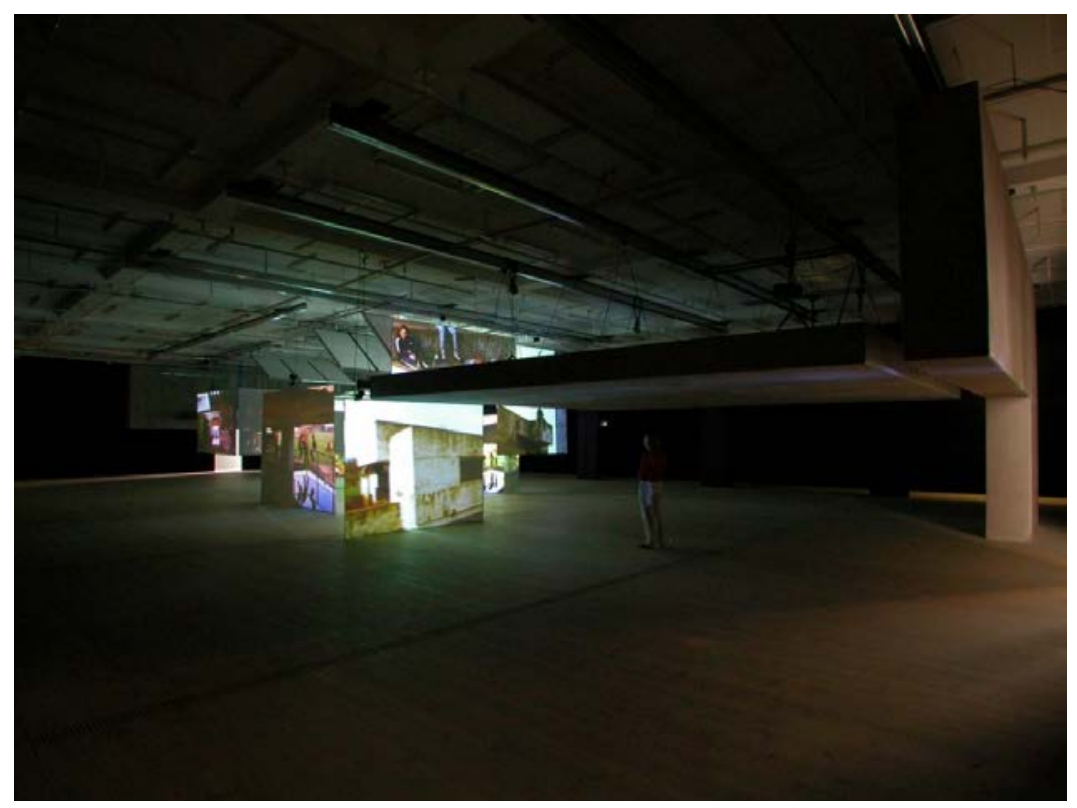

Figura 1: Jane e Louise Wilson, A Free and Anonymous Monument, 2003. Imagem da instalação no BALTIC Centre for Contemporary Art, de 13 de setembro a 30 de novembro de 2003. Foto: Jerry Hardman Jones e Colin Davison. Cedida pelas artistas e Galeria Lisson, Londres.

\footnotetext{
${ }^{7}$ No original, moving way com o duplo sentido de 'móvel' e 'comovente' (N.T.).
} 


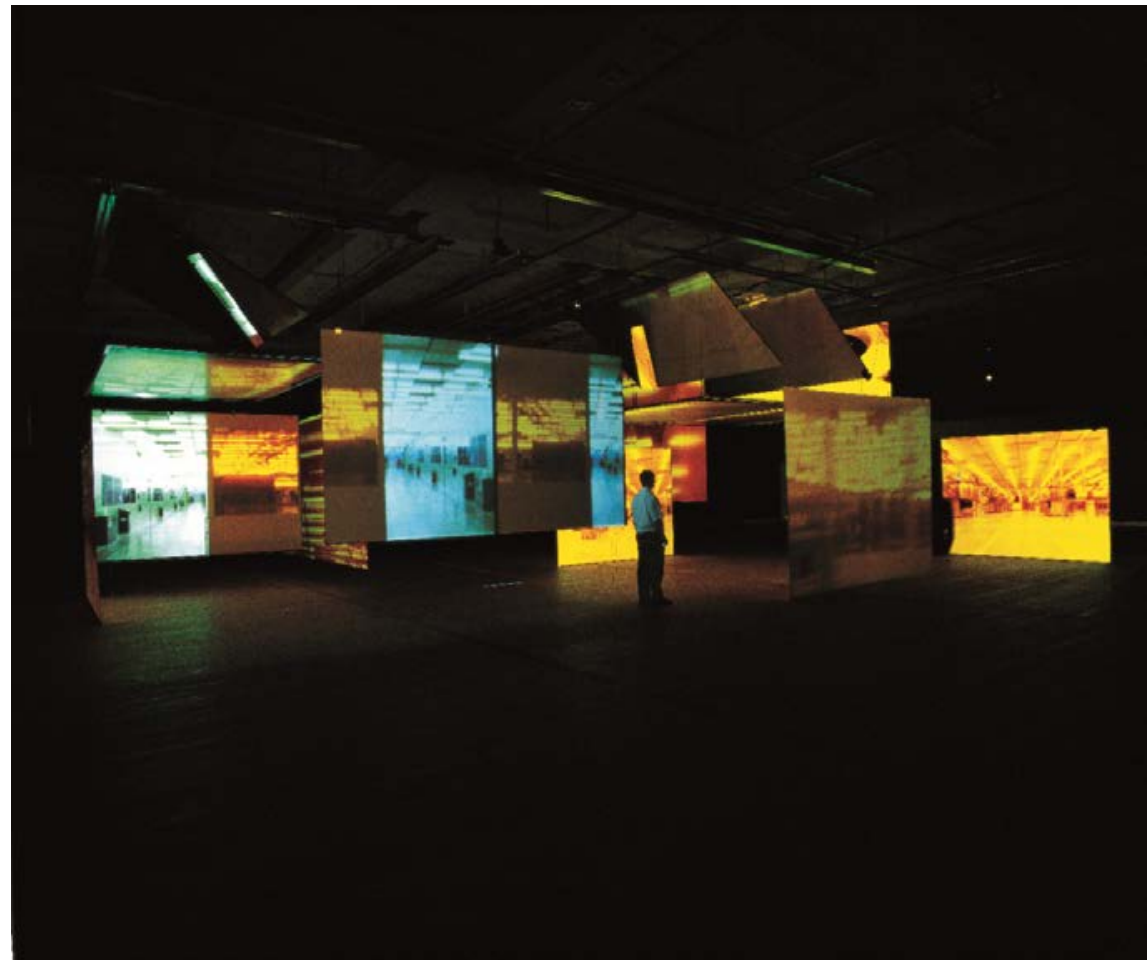

Figura 2: Jane e Louise Wilson, A Free and Anonymous Monument, 2003. Imagem da instalação no BALTIC Centre for Contemporary Art, de 13 de setembro a 30 de novembro de 2003. Foto: Jerry Hardman Jones e Colin Davison. Cedida pelas artistas e Galeria Lisson, Londres.

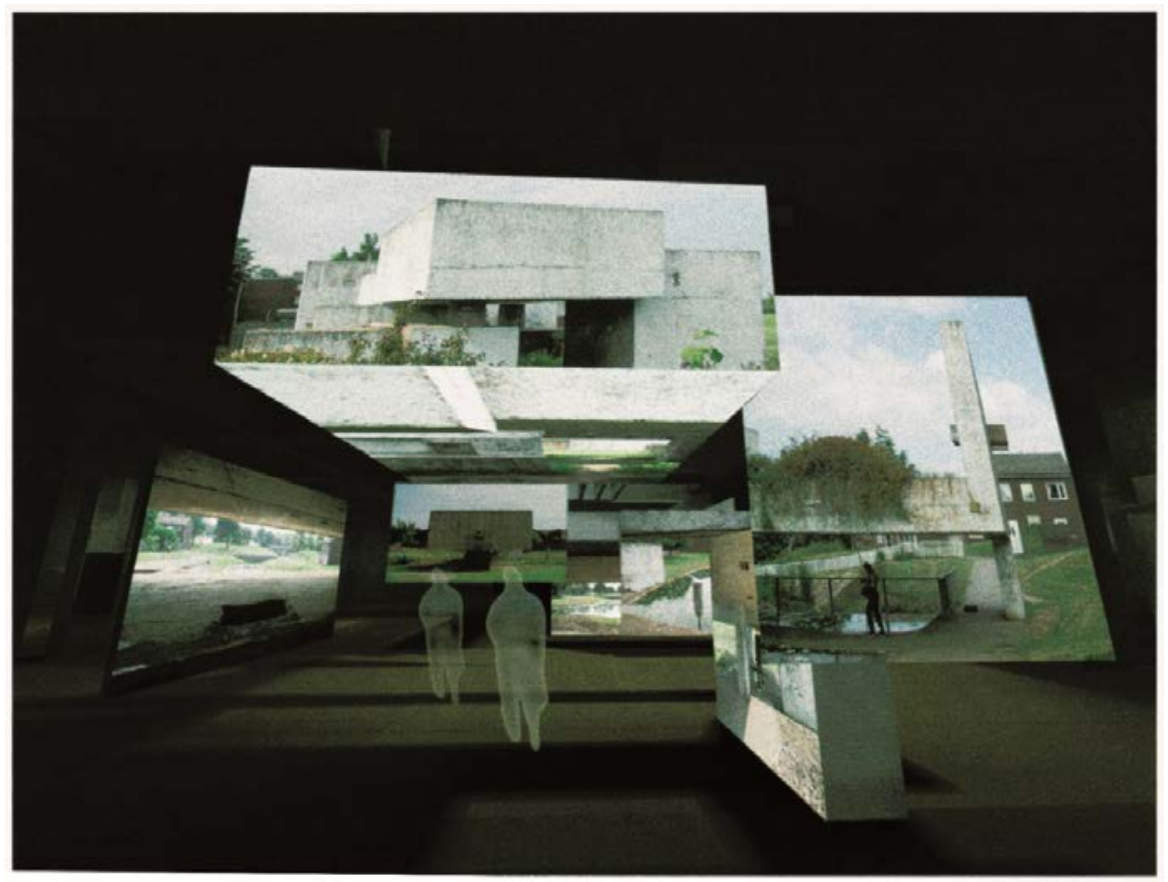

Figura 3: Jane e Louise Wilson, A Free and Anonymous Monument, 2003.

Projeto tridimensional do percurso da instalação, mostrando o Pavilhão Apollo de Victor Pasmore, no BALTIC Centre for Contemporary Art, de 13 de setembro a 30 de novembro de 2003. Foto: Jerry Hardman Jones e Colin Davison.

Cedida pelas artistas e Galeria Lisson, Londres. 


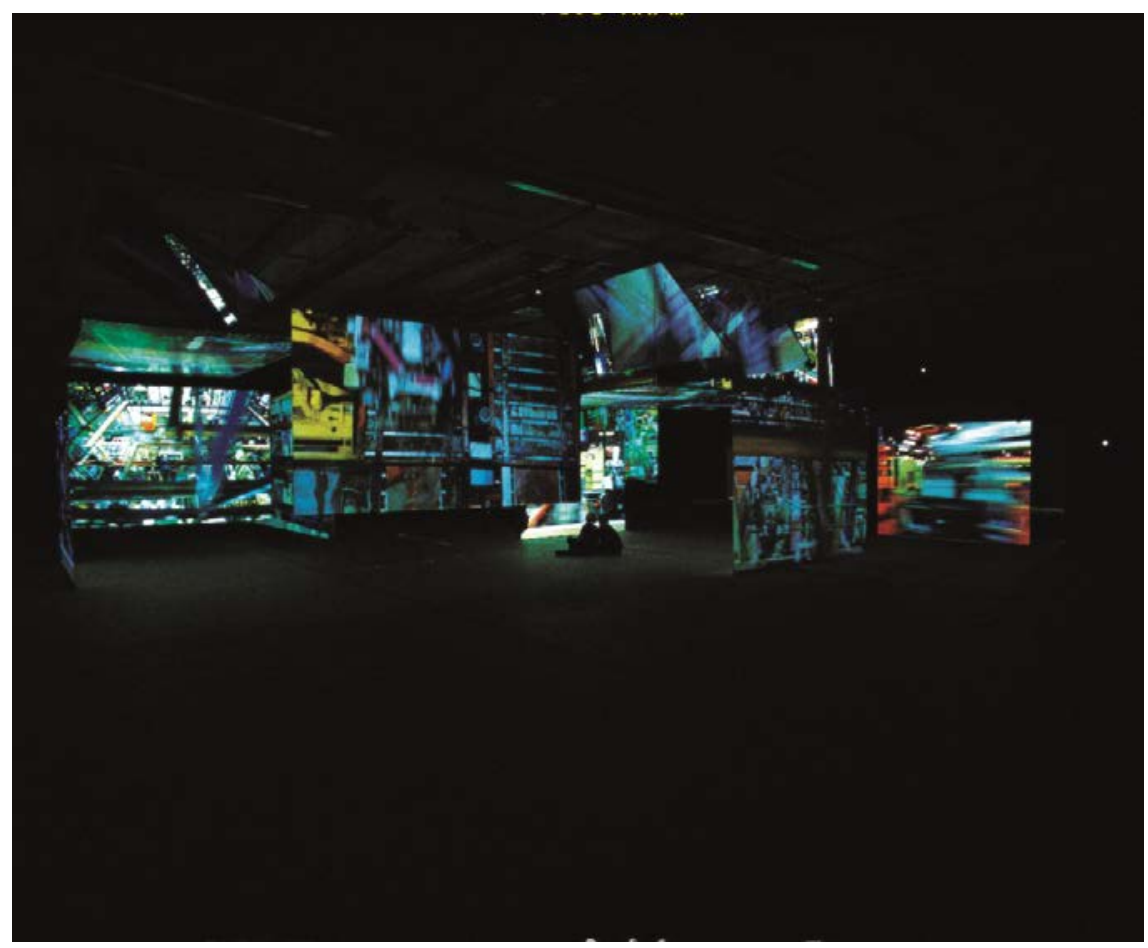

Figura 4: Jane e Louise Wilson, A Free and Anonymous Monument, 2003. Imagem da instalação no BALTIC Centre for Contemporary Art, de 13 de setembro a 30 de novembro de 2003. Foto: Jerry Hardman Jones e Colin Davison. Cedida pelas artistas e Galeria Lisson, Londres.

À medida que o visitante se move pelo espaço, o espetáculo das imagens reflete-se na sombra da sua receção. Silhuetas de pessoas que caminham e observam animam o espaço. E, à medida que o visitante habitual aciona a obra, uma narrativa desenvolve-se cinematicamente, cujo enredo resulta do próprio ato de estar no espaço. Uma história surge a partir do próprio local, emanando da superfície do lugar - da sua pele. Configurada como uma construção em movimento e refletida na forma da receção da obra, a narrativa é aqui uma verdadeira exploração arquitetónica. Ganha forma - por vezes num formato suspenso - a partir da arquitetura interna dos espaços que são examinados e, à medida que se desenvolve, a história é progressivamente moldada, condizendo com esta arquitetura interna. É, por outras palavras, totalmente projetada.

\section{A Instalação como Pavilhão}

À medida que o espaço, progressivamente, conta a sua história em $A$ Free and Anonymous Monument, é construída uma ponte. A trajetória da instalação liga, tanto em forma como em conteúdo, a própria estrutura do Pavilhão Apollo de Pasmore, tornando-a não apenas o elemento mais importante neste projeto espetatorial-arquitetónico, como a real matriz da instalação.

A força motora da instalação de imagem-movimento das Wilson tem mesmo a forma literal de uma ponte. Em muitos aspetos, o 
próprio pavilhão de Pasmore teve esta capacidade. Foi concebido como uma ponte sobre um riacho e conceptualizado como uma plataforma em movimento a partir da qual podíamos ver a paisagem circundante e reunir informalmente. Entrar na instalação re-presenta esta ideia de passagem que se abre para a observação. Inclusive, ela reconstrói de um modo fiel o percurso do pavilhão, reproduzindo sob a estrutura, na verdade, o passeio que podemos fazer no chão do original.

O pavilhão de Pasmore foi também erigido como ponte entre diferentes configurações artísticas, ao tentar uma síntese espacial de todas as formas de arte. Como arquitetura, foi talhado de modo escultórico, definido de modo pictórico, e além disso projetado com um piscar de olho à história do projeto paisagista. A forma final de $A$ Free and Anonymous Monument segue o projeto de Pasmore, uma vez que, também aqui, uma forma de arte torna-se noutra, criando uma relação fluida entre arte e arquitetura.

O Pavilhão Apollo foi construído a partir de várias camadas de formas abstratas e planos lisos que se interligavam para criar uma terceira dimensão escultórica do espaço. Em A Free and Anonymous Monument, os treze ecrãs bidimensionais são colocados à volta do espaço segundo ângulos de visão que sugerem a mesma arquitetura do pavilhão. Os ecrãs são pensados como se fossem campos de visão e posicionados de maneira a aprimorar as intrincadas camadas da intersecção visual presente no pavilhão. Criam o tipo de arquitetura da visão volumétrica e plástica que o próprio Pasmore se esforçou por obter no seu projeto. Além disso, os três ecrãs localizados no chão da instalação correspondem exatamente aos três planos que são os suportes em betão que sustentam o pavilhão na vida real.

A arquitetura de Pasmore transmitia a qualidade háptica do relevo, uma forma de arte que, como notou o historiador de arte Alois Riegl (1858-1905), é apreciada através do toque - pois apenas o toque pode revelar a sua estrutura, forma e nuances (Riegl 1985; Riegl 1993). A Free and Anonymous Monument relembra, de um modo tangível, este aspeto do relevo abstrato de Pasmore. Com cada um dos ecrãs colocados como se fossem o plano de um relevo, sentimos as camadas e a profundidade do espaço. Ficamos fisicamente envolvidos na sua densidade plástica e podemos experienciá-lo de um modo cinestético. O visitante é aqui conduzido para o jogo de luzes e sombras que caraterizam a própria arquitetura do relevo. Em última análise, podemos dizer que os planos de projeção da instalação das Wilson projetam, fenomenologicamente, os planos arquitetónicos da construção artística que evocam.

\section{O Pavilhão, uma Arquitetura Moderna}

A construção utópica de Victor Pasmore era também uma ponte metafórica, na medida em que ecoava estruturas antigas - o pavilhão, 
uma construção típica do princípio da era moderna - ao mesmo tempo que se projetava para o futuro. Ao criarem um monumento ao monumental pavilhão do próprio Pasmore - um ato que se reflete no próprio título da instalação - as irmãs gémeas Wilson produziram um duplo monumento, tão "grátis e anónimo" como um pavilhão, para usar as palavras que Pasmore invocou para a sua própria estrutura. De modo a valorizarmos a profundidade da referência arquitetónica criada neste pavilhão-instalação, neste ponto, poderão revelar-se úteis algumas considerações sobre a história da arquitetura do pavilhão.

O pavilhão era um elemento importante no pensamento da modernidade, usado principalmente em exposições mundiais e feiras $^{8}$. Uma construção grande e aberta concebida para mostrar e acolher atividades e movimento, representava um uso público da arquitetura. Parente de lugares do século XIX como arcadas e grandes armazéns, que muitas vezes tinham a sua forma, o pavilhão de salas de exposição era ele mesmo um lugar de "passagem” pública (termo para arcada em francês). Um sítio de circulação feito para exibir os bens produzidos na era industrial, o pavilhão de exposições universais representava a arquitetura característica da era moderna.

Como arquitetura, o pavilhão tem outro conjunto de conotações relevante para uma compreensão da apropriação feita pelas Wilson deste tipo de forma na sua instalação: a herança do design paisagista na conceção cultural do pavilhão moderno. O pavilhão era uma construção ornamental frequente em parques e jardins públicos. Os pavilhões de jardim eram estruturas arquitetónicas semipermanentes de grande dimensão, luminosas e abertas, que providenciavam abrigo temporário ao mesmo tempo que abraçavam a paisagem em redor. Inseridos numa paisagem, podiam ser usados como um lugar de descanso ou de retiro, mas também de congregação. Os pavilhões iriam marcar o planeamento de um parque, interrompendo o curso dos jardins e o movimento das pessoas através da paisagem. Os pavilhões também eram concebidos como casas de diversão, acolhendo atividades sociais tão diversas como espetáculos, fêtes e música ao vivo. O nome também poderia ser dado a qualquer construção adequada ao divertimento, ou a um sítio anexo a atividades de lazer ou ringues desportivos, construído para o conforto dos espetadores.

$\mathrm{Na}$ era moderna, o pavilhão preencheu a clivagem entre a cidade e o jardim quando se tornou um elemento dos jardins públicos urbanos. No seu duplo uso, o pavilhão era então, totalmente, um lugar para o espetáculo moderno. Tanto como exibição para o comércio de exposições universais, como quintessência arquitetónica de espetáculo em jardins, o pavilhão era arquitetura tornada teatro. Um sítio de exibição pública, um lugar de circulação de pessoas e

\footnotetext{
${ }^{8}$ Para uma introdução geral à cultura da modernidade ver Kern 1983; Giedion 1962; e Giedion 1969.
} 
bens, o pavilhão era uma arquitetura espetacular que abraçava o próprio espetáculo da vida moderna.

O pavilhão, ele próprio um sítio de exposição, consequentemente exibia a cultura da modernidade, pois representava mesmo a arquitetura da mudança percetiva provocada por essa era. Mostrando na sua estrutura a visão moderna, o pavilhão era, em última análise, uma máquina para se ver, e para se ver de um modo diferente. Esta arquitetura luminosa começou por ser uma arquitetura da luz. Vestígio de um espaço exterior, o pavilhão estava aberto à luz solar e dava corpo à leveza. Exigia uma forma mais ágil e menos tectónica. Tanto como um exterior-dentro, como um interior aberto o ar livre, tal arquitetura acabou com as fronteiras entre o exterior e o interior e criou um espaço entre os dois. Além disso, a abertura do pavilhão incorporou uma inclusão social que desafiava uma exclusão espacial elitista e privatizada. Concebido como um espaço social que era público, o pavilhão reforçou o próprio sentido de público e a sensação cinética de espaço feito para e utilizado por um público.

$\mathrm{Na}$ verdade, o pavilhão iria reunir a atividade pública vinda da circulação de sítios diferentes e iria juntar bens, eles próprios vindos de longe, não apenas nele mas através dele. Historicamente, podemos associar-lhe pontes e passeios em movimento, linhas de comboio e barcos a vapor, altos arranha-céus e a mobilidade dos meios de comunicação. O pavilhão era o modelo arquitetónico de todos esses meios de transporte e lazer, ou seja, das máquinas da mobilidade que caracterizaram a modernidade e albergaram as diferentes movimentações da mobilidade social. Este cinético lugar de exposições mostrava as transformações percetivas, culturais e sociais do espaço que ocorreram na era moderna.

\section{Visões de Circulação, Espaços Fraturados}

A arquitetura do pavilhão ilustrava o facto de, na era moderna, o espaço não poder continuar a ser pensado como estático e contínuo. Como um resultado da modernidade, o espaço tem sido radicalmente mobilizado e novos horizontes de ver têm aparecido. Como o espaço era dinamicamente percorrido por novos meios de transporte e comunicação, eram reveladas novas perspetivas e surgiram novos e múltiplos planos visuais. O campo percetivo tornou-se descontínuo, destruído e fraturado. Como resultado desta radical mobilização cultural, o nosso campo de visão mudou de uma forma evidente, tornando-se naquilo que é hoje para nós: disjuntado, separado, fragmentado, multiplicado, móvel, transitório e instável.

A nova paisagem visual também é resultado da entrada do cinema neste cenário. Nascidas da mobilidade da visão da modernidade, as imagens cinematográficas encarnavam a própria geografia da modernidade. As exibições de cinema disjuntavam o espaço em movimento. O cinema introduz uma linguagem feita ex- 
clusivamente de cortes e movimento, de múltiplos e fragmentados planos visuais. O cinema é, além disso, a quintessência do espaço público: um espaço inclusivo de reunião social e de circulação de público bem como um sítio de espetáculo. Visto nesta perspetiva, as imagens cinematográficas juntam-se ao pavilhão como agentes da mobilização do espaço visual - aquilo que nos transforma em espetadores e sujeitos modernos.

\section{Um Pavilhão da Imagem Arquitetónica}

Com este pano de fundo, podemos apreciar completamente A Free and Anonymous Monument como um monumento complexo - uma estrutura mnemónica agregada - uma construção feita, em grande parte, de múltiplos níveis e planos de lembranças. Desbravando o terreno deste monumento, descobrimos vários estratos de memória arquitetónica, construída à volta da ideia de pavilhão, inscrita na impressionante composição visual da instalação. Em última análise, o modelo da obra deriva do ato de separação entre a arquitetura visual do pavilhão e a sua própria história.

A monumental reconstrução de Pasmore deveria revitalizar uma área urbana pós-industrial, devolvendo-lhe o sentido de espaço público. Assim, a atração de Jane e Louise Wilson, ao refazerem um remanescente desta forma, pode ser, em parte, explicada pela lembrança desta função vital do pavilhão, concebido como uma construção pública, como um grandioso espaço público. A obra é apresentada como uma arquitetura que deve ser pública e de que qualquer um se possa apropriar.

O que aqui está em causa é a apropriação. A memória do uso público do pavilhão, enquanto arquitetura do divertimento e lazer, é lembrada quando nos mostra como a juventude local se reapropriou do degradado pavilhão para uso próprio. A divertida estrutura de Victor Pasmore (ela própria uma paródia aos antigos pavilhões de jardim) é retomada à medida que os jovens regressam lá para a transformarem num lugar de divertimento. Uma zona gratuita, um ponto de encontro não institucionalizado, o pavilhão é, mais uma vez, o sítio de diversão. Tal implica brincar com a própria estrutura da construção, retirando da sua arquitetura todas as oportunidades para a diversão, transformando o pavilhão numa versão urbana para escalada em rocha. De forma significativa, as imagens da instalação mostram-nos como os utilizadores reutilizaram elementos estruturais dos lados da construção como plataformas de escalada. Este espaço de recreio é agora verdadeiramente "usufruído".

Jane e Louise Wilson continuam a brincar com a estrutura do pavilhão à medida que elas evocam a sua função como ponto de descanso num passeio pelo jardim e como eixo de múltiplas perspetivas em movimento. O cenário da instalação é composto como se fosse precisamente desenhado neste mapa da visualidade moderna. A ma- 
triz visual gerada a partir da arquitetura do pavilhão é aqui reinventada, desta vez, em imagens em movimento.

De um modo transparente, a instalação das Wilson reformula o estatuto itinerante do pavilhão como passagem, enquanto constrói visualmente a sua função como plataforma de observação. A instalação - um espaço múltiplo de travessia da imagem - é um permeável campo de circulação da observação. Uma vez que os ecrãs não têm moldura e parecem suspensos no espaço, temos uma vista desimpedida. A textura dos ecrãs reforça esta abertura. De fato, os ecrãs de dupla face têm a mesma resolução de imagem e dão-nos a mesma clareza visual em ambos os lados. Consequentemente, vemos com clareza em qualquer ponto da instalação. Projetado deste modo, este é um espaço de luz. A luminosa zona visual é ainda imaginada como um espaço de luz e incorpora ainda mais uma leveza do ser. Mais uma vez, por causa do enquadramento aberto e da estrutura do ecrã, não nos sentimos nem dentro nem fora do cenário. Tal como acontece na ágil arquitetura do jardim do pavilhão, há aqui um jogo visual entre interior-exterior. Neste sentido, A Free and Anonymous Monument espelha realmente o projeto visual do pavilhão - uma luminosa arquitetura da luz.

Um plano para se caminhar, sobre e dentro, o espaço da instalação redesenha o caminho do jardim oferecendo-nos peculiares planos visuais. Ao olharmos para o multifacetado desenho da instalação somos lembrados de que veríamos de um modo diferente se caminhássemos por um pavilhão de jardim. O cenário iria mudar, de igual modo, à medida que avançássemos no espaço, dando aos espetadores diferentes vistas e panoramas. Seriam mesmo perspetivas diferentes. Neste caso, o mesmo efeito é alcançado quando o nosso movimento na multifacetada plataforma recria as polivalentes perspetivas de uma paisagem visual complexa. À medida que são desenhados no mapa da instalação, planos visuais, intensivamente diferentes, são literalmente imaginados em movimento.

A Free and Anonymous Monument também evoca o estatuto visual do pavilhão como um divertimento. É um monumento ao prazer visual desta plataforma visual, instalado numa fluida paisagem visual. Para se ver a partir dele, o pavilhão é projetado para fora da sua própria diversidade visual. Na instalação, como que para aumentar o efeito do pavilhão, este efeito especial é reproduzido através de imagens em movimento apresentadas a partir de diferentes ângulos na complexa planaridade visual. A diversidade visual que emana da textura dos planos de projeção funciona, igualmente, em resultado da forma e do formato dos ecrãs. Cada ecrã tem uma proporção específica e todos os ecrãs são projetados em diferentes tamanhos. O resultado do espaço visual fragmentado parece explosivo, e espelhos ampliam este efeito caleidoscópico. Três espelhos angulares, colocados sobre a instalação, refletem e amplificam o espaço. Assim, um 
verdadeiro espetáculo de imagens envolve o espetador nesta sala de espelhos.

Do mesmo modo que A Free and Anonymous Monument disseca a espetacular função do pavilhão como um mecanismo para ver, e ver de um modo diferente, ele também nos lembra a forma como o pavilhão representava não apenas o nascimento do espetáculo moderno mas também do sujeito moderno - aquilo a que Charles Baudelaire chamava poeticamente de "observador apaixonado... um caleidoscópio dotado de consciência” (Baudelaire 1993, 18).

Ao manter este pensamento da modernidade, a instalação celebra a natureza múltipla, fraturada, disjuntada, fluída e instável do espaço moderno. O planeamento dos ecrãs e as imagens nas suas superfícies formam uma verdadeira exposição da cultura urbana e da industrialização. Por exemplo, tal como são mostrados vários lugares da modernidade (uma fábrica, uma plataforma petrolífera), lembramo-nos dos pavilhões das salas de exposição e de exposições internacionais, com a sua capacidade de mostrar - reunir - não apenas os produtos mas a verdadeira essência da vida moderna.

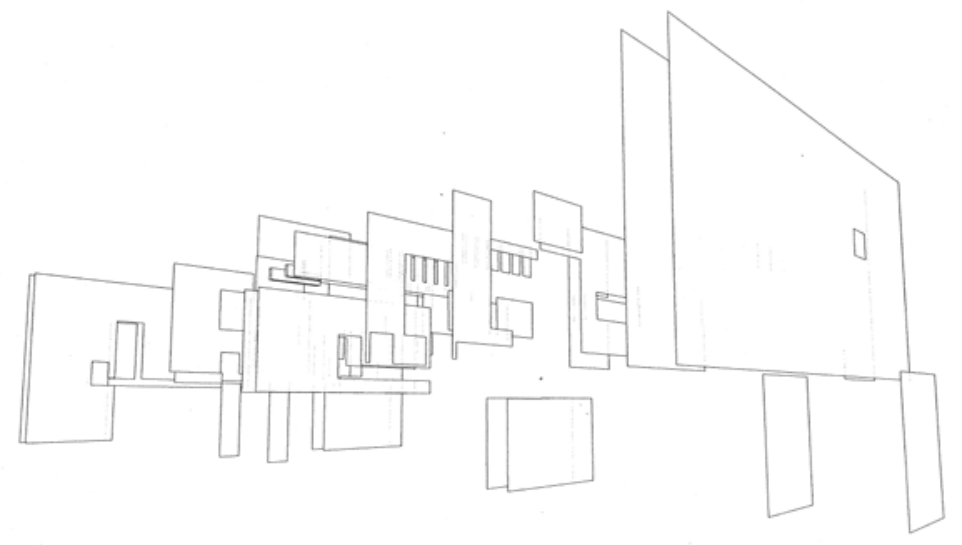

Figura 5: Jane e Louise Wilson, A Free and Anonymous Monument, 2003.

Desenho axonométrico da instalação no BALTIC Centre for Contemporary Art, de 13 de setembro a 30 de novembro de 2003. Cedida pelas artistas e Galeria Lisson, Londres.

O conjunto de ecrãs como planos visuais fragmentados, em movimento, ecoa a montagem de sequências mostradas nas suas superfícies. A este respeito, Jane e Louise Wilson são mulheres com uma câmara de filmar, cujo kino-olho está especialmente sintonizado com a história cinemática da montagem. Quase sempre estas artistas filmam em película em vez de vídeo, preferindo a articulação da linguagem do cinema com a montagem e a textura granulada da imagem ${ }^{9}$. A montagem dos efeitos da industrialização não é apenas de natureza histórica, mas filmada na tradição do cinema modernista.

\footnotetext{
${ }^{9}$ Reuni esta e outras informações sobre o método de trabalho das Wilson através de entrevistas realizadas às artistas em Governors Island, no dia 23 de junho de 2004, e em Nova Iorque, no dia 1 de julho, 2004. Agradeço a Jane e a Louise Wilson o seu generoso contributo.
} 
Os cortes levam-nos, de uma forma imaginativa, das práticas de montagem dos anos 1920 ao coração do incessante movimento do cinema estruturalista. Em última análise, como que evocando a tendência de Sergei Eisenstein em ligar "montagem e arquitetura", A Free and Anonymous Monument revisita, em múltiplos ecrãs, este conjunto arquitetónico modernista e rítmico (Eisenstein 1989, 111-131) ${ }^{10}$.

\section{Uma Arqueologia Industrial}

Em Metropolis, das Wilson, o espaço urbano é acionado tal como o espaço industrial é animado, ambos pulsando com a vida da máquina. Como que emergindo do pavilhão central - ele próprio uma máquina do visível - aparecem outros espaços da modernidade e industrialização. Criando um conjunto de zonas industriais, as artistas levamnos numa específica viagem regional, explorando lugares na região de Newcastle. Estes outros lugares na região da intervenção urbana de Pasmore resultam do leque visual do degradado pavilhão, abrindo-se à observação desta plataforma de ver em movimento.

A arqueologia urbana das Wilson deve muito à noção de Kuleshov de que a montagem permite uma "geografia criativa". A inventiva topografia industrial das irmãs é uma história geográfica de conjunto, uma crónica que cobre todo o espectro da era industrial, da reprodução mecânica à representação digital. Nesta instalação, viajamos de uma visão do motor e da mecânica das perfurações de petróleo até à engenharia digital, à medida que avançamos da fábrica de motores de Cummins em Darlington para Atmel, um laboratório high-tech em North Tyneside. Viajamos, em concreto, do trabalho interno de verdadeiros motores para uma fábrica que produz motores modernos: os microchips de computador conduzem as máquinas da nossa vida digital tecnologicamente definida.

No mesmo mapa criativo encontramos o parque de estacionamento abandonado de Gateshead, uma estrutura de vários andares retratada nesta instalação de imagem-movimento como referência ao seu uso como cenário em Get Carter (filme realizado por Mike Hodges em 1971). Completando a paisagem pós-industrial, e após um regresso à imagem do Pavilhão Apollo, é-nos mostrado uma plataforma petrolífera no mar alto, uma estrutura icónica associada ao Mar do Norte.

A sequência de imagens em loop (da memória) começa com planos do Pavilhão Apollo vazio. À medida que o espaço vai sendo animado por jovens que energicamente sobem as suas paredes, a obra de arte das Wilson é acionada. Devido à localização e à escala dos ecrãs, os jovens parecem, num efeito de repetição, estar mesmo a subir as evanescentes paredes-ecrãs que compõem a instalação.

\footnotetext{
${ }^{10}$ Este texto foi escrito em 1937 para ser incluído num livro.
} 
Na sequência que mostra o Pavilhão Apollo, todas as imagens mostradas nos treze ecrãs são diferentes. Esta pluralidade de pontos de vista é ampliada pela assincronicidade da montagem, com o seu staccato tempo, pois os cortes surgem em tempos diferentes nos diferentes ecrãs. Materializam-se a própria multiplicidade visual e fragmentação que víramos na arquitetura do pavilhão, caraterística da montagem da espaço-visualidade moderna. A sua ideia reflete-se na estrutura multiforme da montagem: uma composição fraturada com um ritmo disjuntado. À medida que as imagens do Pavilhão Apollo se desenrolam, o ritmo da instalação parece compósito e instável, com imagens a dançar nos ecrãs em diferentes compassos.

A forma da representação muda noutras sequências nas quais os espaços são menos ocupados. Neste caso, os cortes ocorrem simultaneamente em todos os ecrãs, criando menos uma fragmentação visual e mais um sentido expandido de paisagem. Um ritmo ambiental permeia agora o espaço da instalação, tornado contínuo pela montagem sincronizada. Desenvolve-se um estado de espírito com as imagens que se movem e que mudam conjuntamente de uma forma rítmica. A história da paisagem industrial desliza por todo o espaço do ecrã expandido. Tal história é, em grande parte, uma psicogeografia.

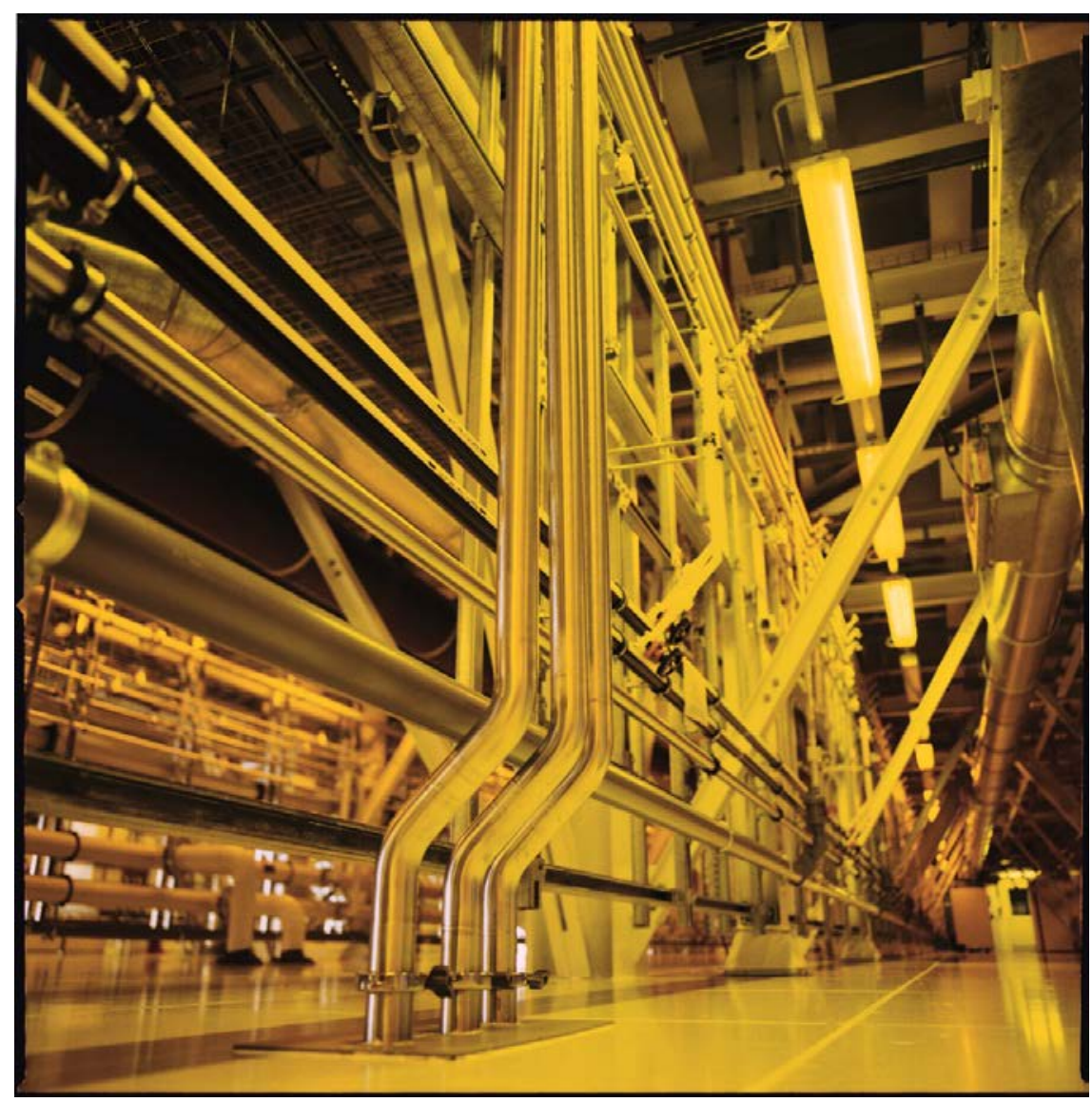

Figura 6: Jane e Louise Wilson, A Free and Anonymous Monument, 2003.

Imagem de Atmel da instalação no BALTIC Centre for Contemporary Art, de 13 de setembro a 30 de novembro de 2003. Cedida pelas artistas e Galeria Lisson, Londres. 


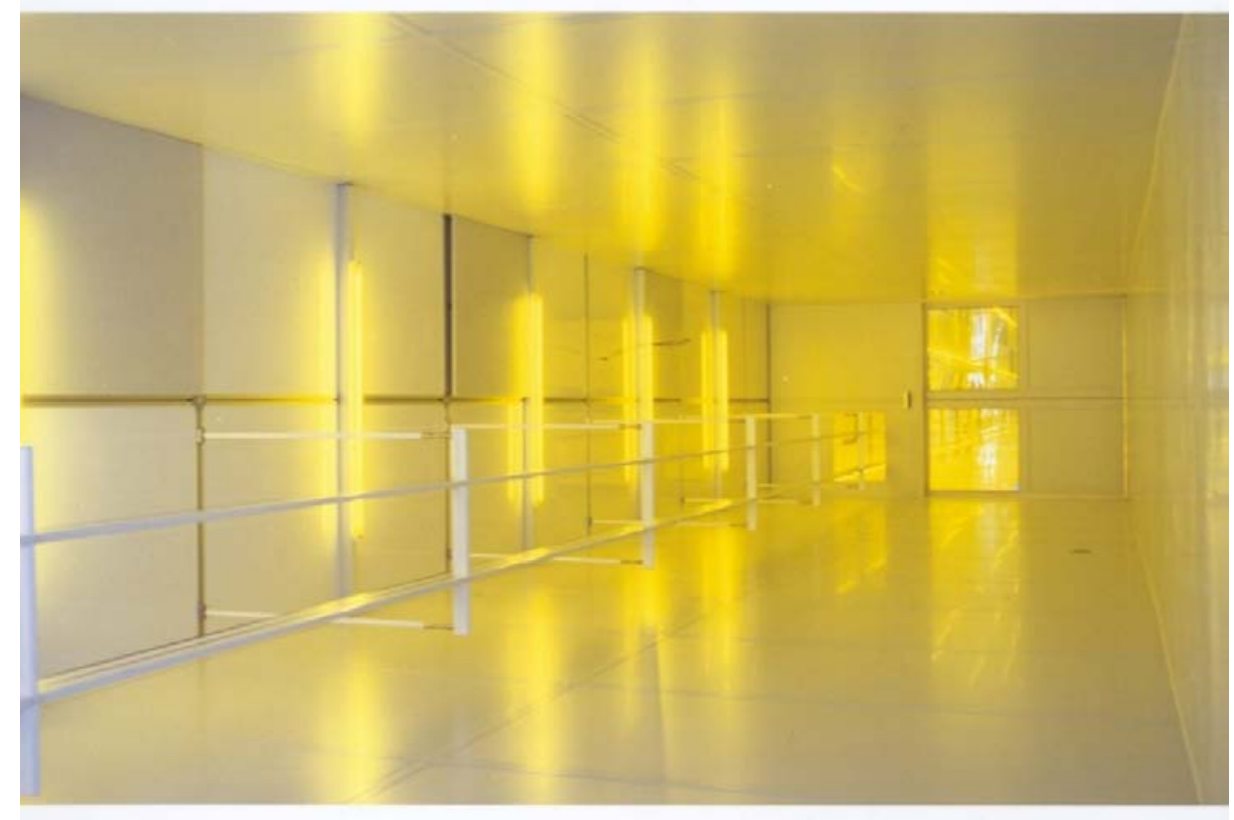

Figura 7: Jane e Louise Wilson, Corridor, Safe Light, 2003.

Impressão C de alumínio em perspex de A Free and Anonymous Monument, 2003. Cedida pelas artistas e Galeria Lisson, Londres.

\section{A Psicologia da Arquitetura}

O planeamento urbano é um processo cinético cujo ponto fulcral é interior... O planeamento urbano... [envolve] todo o domínio da psique humana.

Victor Pasmore

Em A Free and Anonymous Monument, os espaços são encenados e cortados pelo kino-olho com a incisividade que caracteriza o gesto de cortar num espaço abandonado e vazio de Gordon Matta-Clark, aqui reinventado cinematicamente ${ }^{11}$. Jane e Louise Wilson não olham apenas para o espaço; elas aprofundam-no, acedendo cineticamente ao seu interior. No seu trabalho, são expostos os trabalhos internos da arquitetura.

Com a marca do seu caméra-stylo, estas artistas esforçam-se por criar o tipo de projeto favorito de Victor Pasmore: elas pretendem traçar a composição psicológica de um espaço arquitetónico. $A$ Free and Anonymous Monument prolonga o entendimento que Pasmore tem da arquitetura como um espaço psicológico e mostra que, de fato, artistas e arquitetos falam a mesma língua quando concebem ambientes urbanos e artísticos como espaços através dos quais nos movemos não só fisicamente, mas também imaginativamente. De um modo geral, quando nos movemos pelo espaço um constante duplo movimento conecta topografias interiores e exteriores (Bruno 2002).

\footnotetext{
${ }^{11}$ Sobre o artista Gordon Matta-Clark, ver Lee 1999.
} 
A paisagem exterior é transformada num mapa interior - a paisagem em nós - ao mesmo tempo que, inversamente, projetamos para fora, no espaço que atravessamos, o movimento das nossas próprias emoções. O espaço é, completamente, uma questão de sentimento. É uma prática que envolve a mudança psicológica em relação ao movimento.

Assim, o projeto de arquitetura envolve um projeto mental. Ao reconstruírem este aspeto do plano de Pasmore, Jane e Louise Wilson acionam a conceção geopsicológica da arquitetura, seguindo de perto o caminho de Pasmore e usando a sua ideia de que o planeamento urbano é uma questão de interiores - um processo cinético correspondente a um movimento interno. De fato, este processo interno estende-se à memória e as próprias memórias projetam-se num espaço. Elas são traços inscritos em lugares. Tal como A Free and Anonymous Monument atesta, as memórias são "arquitetadas" - projetadas - em movimento.

Nesta instalação, vemos realmente o trabalho da memória. Traços de um mundo industrializado são concebidos como sonhos mnemónicos - arquiteturas mentais. O espaço da instalação é oniricamente povoado por máquinas. A ambiência é dispersa mas não imaculada. Abandono, obsolescência e entropia surgem desta paisagem mental. Assim como a arquitetura cria um estado de espírito, também o desenho desta instalação faz. Apesar de vários estados mentais surgirem à superfície do ecrã, o estado de espírito que prevalece, assombrado pela melancolia, nunca é de nostalgia.

Não sentimos uma celebração da máquina. Nem experienciamos abjeção nesta paisagem bastante mecanizada. Pelo contrário, a instalação das Wilson exala um sombrio sentido de solenidade. O sentimento parece apropriado ao esforço monumental de registar uma história da industrialização regional e da sua morte. A grandeza, graça e elegância da paisagem industrial surpreende-nos. Ao percorrermos a instalação, somos tomados por uma enorme sensação de solidão. A beleza interior das máquinas revela-se o único habitante do espaço.

Por vezes, estranhos braços mecânicos e a mecânica da robótica são mostrados numa montagem clamorosa. Depois, de repente, o estado de espírito muda. Num espaço de ausência, as pessoas tornamse robots. Entramos no mundo do laboratório Atmel, o nosso contemporâneo mundo digital, e vislumbramos o nosso futuro. Curiosamente, enquanto o barulhento mecanismo de produção de motores e perfurações petrolíferas são totalmente mostradas, as imagens de Atmel mostram a aparente invisibilidade que distingue a conceção da nossa era digital.

Surge um espaço belo e claro. É um sítio arquitetónico vasto e bastante estéril que estranhamente se parece com uma sala de operações. É completamente cirúrgico. E não surpreende que tal estado de espírito predomine aqui pois, como viremos a descobrir, o ambiente 
imaculado e bastante protegido permite que os trabalhadores "operem" em chips de computador.

A luz no espaço não é apenas notável, como cria ambiente. Cria ambiência, uma atmosfera, um estado de espírito. Sentimo-nos dentro do espaço iluminado. E até percebemos a razão: o processo físico de gravar num chip de silício exige o uso de um tipo específico de iluminação fotográfica. O processo fotolítico utilizado nesta gravação digital é, de fato, fotogénico. Este espaço de amarelo brilhante é pura, absoluta leveza.

Tal atmosfera luminosa tem-se adequado à sensibilidade de Jane e Louise Wilson, que têm capturado uma fotográfica paisagem de luz e têm-na reativado com imagens em movimento. A instalação mostra este espaço de luz como um campo de energia. Está exposto um reservatório elétrico de energia: a luz como uma força da vida. O laboratório Atmel pulsa com energia quando a câmara revela a corrente desta arquitetura de luz. Quando andamos pela instalação entramos nas entranhas do laboratório. São bastante amplas, uma vez que os quatro pisos de Atmel são usados exclusivamente para alimentar o único piso da operação. Com tal mecanismo invisível construído no seu esqueleto, o edifício é sentido de forma corpórea. Este espaço de luz é um organismo de pleno direito.

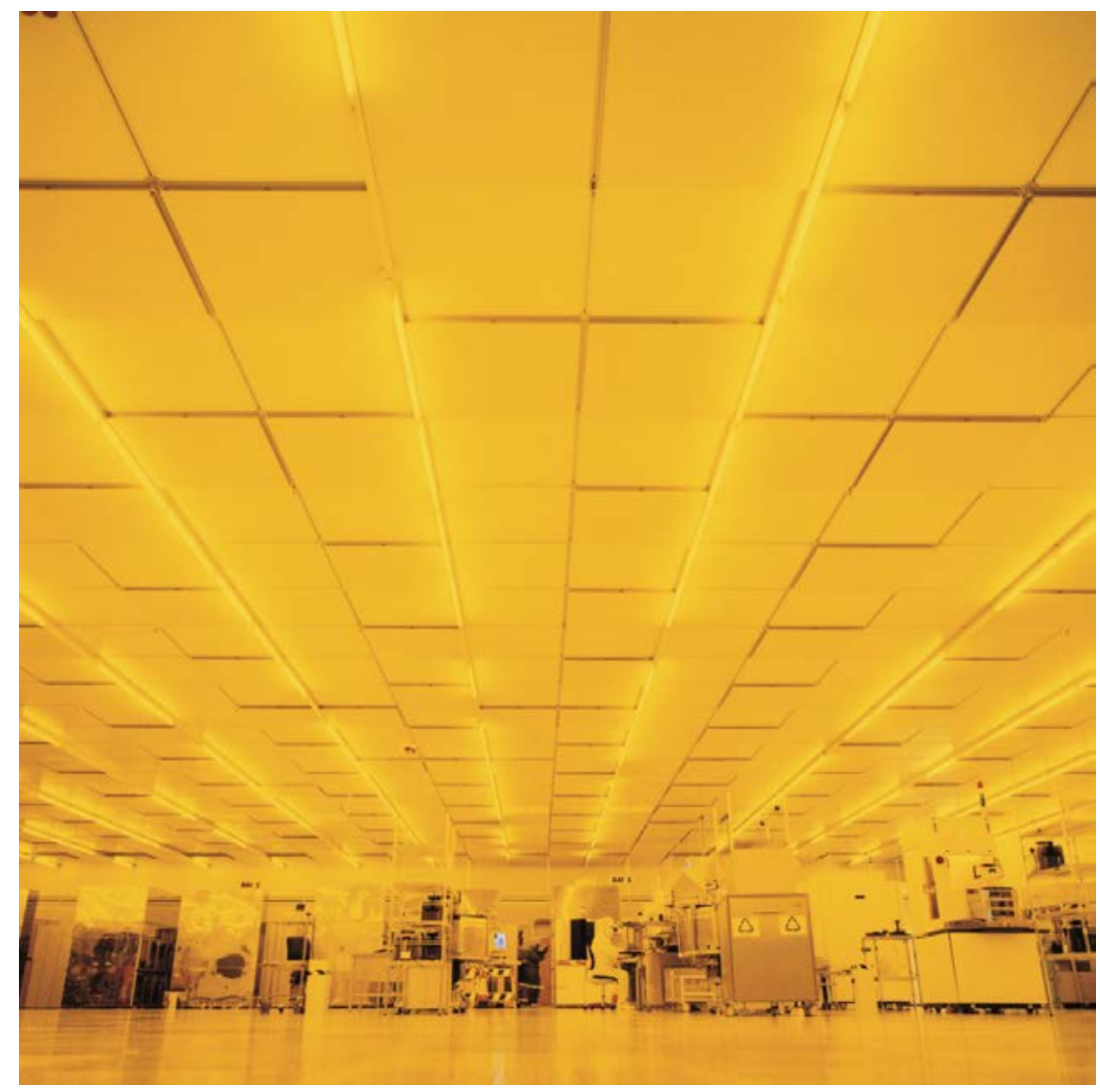

Figura 8: Jane e Louise Wilson, Ballroom, Safe Light, 2003. Impressão C de alumínio em perspex de A Free and Anonymous Monument, 2003. Cedida pelas artistas e Galeria Lisson, Londres. 
À medida que deslizamos pela paisagem amarelada, a sequência torna-se hipnótica. O espaço fica suspenso. Mas este suspense não é estimulante. Pelo contrário, sentimos uma tensão sussurrante: o estado suspenso de persistir, pairando na nossa cabeça. Estamos expectantes, à espera, divagando no espaço mental. De fato, está aqui representada uma arquitetura mental: um estado mental pensativo. É um verdadeiro espaço interior iluminado.

Ao exporem este tipo de mecanismo interno, as Wilson mostram como se apropriaram completamente da lição de arquitetura de Victor Pasmore. Como ele afirma, "o espaço urbano é interior como o interior de uma casa" (Pasmore 1980, 261). De fato, a paisagem urbana é um trabalho mental. É um vestígio das memórias, da atenção, da imaginação, e dos afetos dos passageiros-habitantes que o atravessaram em diferentes tempos. Tal inclui-nos a nós, espetadores de uma instalação de imagem-movimento. Em última análise, Jane e Louise Wilson mostram que as imagens em movimento são a projeção dos nossos trabalhos internos - a arquitetura das nossas mentes.

\section{Paisagem Sonora}

À medida que a complexa arquitetura audiovisual de A Free and Anonymous Monument aciona a imaginação do espetador, a sua estrutura participante substitui a habitual imagem de controlo e vigilância associada à máquina e à era digital para envolver a própria liberdade anónima que o visitante tem para vaguear pela obra. A geometria visual da instalação desafia o modelo de panótico que, de alguma forma, esteve na origem de uma parte das anteriores obras de arte que as Wilson fizeram ${ }^{12}$. Implodindo todas as estruturas de controlo, a instalação também vai para além da simetria da visão estereoscópica que caraterizava os suas anteriores obras. A metáfora visual para a dupla visão das gémeas é aqui encerrada a favor de uma montagem arquitetónica complexa, em camadas, que é não apenas visual mas também auditiva.

Na verdade, a arquitetura psicológica exposta aqui não é completamente uma questão visual. A psicologia da arquitetura também é, talvez principalmente, uma função do som, que é uma estrutura interna na articulação do espaço mental. Aqui, ela é feita pelo próprio mecanismo da instalação. Cada ecrã tem uma coluna apenas emitindo o seu som, de tal modo que nos podemos deslocar pelo espaço da instalação seguindo os sinais sonoros. O som guia-nos pela obra, orientando-nos ou confundindo-nos. Pode-nos fazer dar passeios ou desvios. Fundamentalmente, o som localiza-nos. E localiza o estado de espírito.

\footnotetext{
${ }^{12}$ Ver, por exemplo, os ensaios de Jeremy Millar e Claire Doherty (Millar e Doherty 2000), o ensaio de Peter Schjeldahl (1999, 4-5) e o diálogo entre Lisa Corrin e Jane e Louise Wilson (Corrin 1999, 6-15).
} 
O ambiente auditivo de $A$ Free and Anonymous Monument articula-se com cuidado, à medida que é criada uma paisagem de sons. A instalação é permeada por sons específicos, vindos de sítios diferentes. Assim, o realismo espacial que surge na instalação deriva não apenas da estrutura visual mas da estrutura auditiva da obra. O som permite-nos não apenas localizar um sítio mas sentir o espaço. Desta comunicação auditiva surge uma mudança no ambiente. Sentimos as diferentes atmosferas, os vários estados de espírito do lugar, pelo modo como ressoam. Podemos ouvir realmente os estados de espírito, e ouvi-los mudar. Por fim, é o som que nos dá uma sensação de lugar. O som é o genius loci - o verdadeiro espírito do lugar.

Em A Free and Anonymous Monument, a montagem sonora tem um espírito próprio. Atravessamos todo o espectro da sonoridade industrial: ouvimos os sons intensos da mecanização, experienciamos a música da produção e a suave melodia do automatismo. Acedemos ao clamor e ao ruído, ao zumbido e ao estrondo, ao tilintar e ao chocalhar, ao choque e ao esmagamento. Ruídos estridentes, rugindo e explodindo, ecoam tumultuosamente através do espaço. Há uma pausa depois. Sabemos que chegámos a uma zona diferente. Contrastando com os sons dos motores de Cummins, no laboratório Atmel há uma misteriosa quietude, uma estranha tranquilidade automática. Ouvimos apenas ruídos de silvos que, na verdade, parecem cintilar através do espaço silencioso. O silêncio é interrompido, em cadência, por zips e bips, por bips e pios, por chios e cliques.

Uma coreografia auditiva é posta em movimento na instalação das Wilson, à medida que os sons criam um ritmo, um tempo: ele sobe, diminui, e sossega. Esta coreografia rítmica é especialmente conseguida na sequência da perfuração petrolífera. É uma verdadeira sinfonia. Está tudo em silêncio durante trinta segundos antes que o som surja e aumente. O barulho dos ruídos de perfuração contrasta com o silêncio contemplativo de uma paisagem marítima. A solitária plataforma de perfuração parece flutuar à superfície da água. Ao pôrdo-sol, limita-se a permanecer nesta paisagem emudecida, pairando sobre a linha do horizonte. No espaço de uma montagem auditiva, viajámos do energético mecanismo de Vertov para a sublimidade de uma paisagem de Turner.

$\mathrm{Na}$ instalação, os silêncios são também sons que criam ritmo. As pausas permitem-nos escutar as máquinas, e não apenas ouvi-las. Não se limitam a fazer ruídos mas são animadas pelo som. Tal como os humanos, as máquinas emitem sons interiores. Os seus ruídos têm uma caraterística distinta - uma personalidade. É como se fossem máquinas pensantes. Cada tom aproxima-nos dos seus trabalhos interiores e para o modo como acionam um edifício. Quando escutamos com atenção, conseguimos aceder não apenas à mente do edifício mas à sua alma. 
Até certo ponto, um mecanismo mental é exposto nesta instalação sonora: os próprios ruídos do nosso cérebro. A sinfonia das Wilson varia em tom, da quietude da mente até à tagarelice que inquieta as nossas cabeças. O estado de espírito da instalação não só é variado como é modulado. Podemo-nos sentir estimulados ou esmagados por todo o clamor de motores a trabalhar. Podemo-nos perder na automática serenidade meditativa dos sons calmos de Atmel. Ou podemos recear a ausência de turbulência auditiva. Por fim, pode-nos obrigar a entrar no silêncio da nossa mente.

\section{Sítios Sem Poder}

A escavação feita por Jane e Louise Wilson na psicologia da arquitetura, até ao ponto em que sabemos como soa, familiariza-nos com um uso específico da arqueologia. Como uma arqueologia da modernidade, A Free and Anonymous Monument representa o culminar da sua meditação sonora sobre as ruínas arquitetónicas e a obsolescência tecnológica. É uma expressão amadurecida de muitos dos temas que têm surgido em obras anteriores das artistas e a sua estrutura suspensa e mnemónica reforça a afinidade com as arquiteturas mentais presentes no seu trabalho anterior.

Pensemos, por exemplo, em Stasi City (1997) e em Gamma (1999): cada um consiste em dois pares de projeções nas paredes que se encontram em dois ângulos de 90 graus, diagonalmente opostos um do outro. O resultado arquitetónico destas instalações - dois pontos de vista mostrados simultaneamente e ligados entre si - reflete uma arquitetura psicológica. Esta arquitetura visual revela o tipo de visão dupla que carateriza a ligação que une estas artistas, que são irmãs gémeas verdadeiras. Concebido num enquadramento duplo, uma instalação das Wilson quase nunca é um só trabalho mas, na maior parte, irmanado, como acontece com Gamma e Stasi City, obras duplas ligadas entre si.

Gamma foi filmado na anterior base aérea dos Estados Unidos em Greenham Common, uma operação da Guerra Fria que albergou armas nucleares e que agora é um lugar desmantelado. A instalação inspeciona sítios de inspeção e de vigia, salas de controlo e zonas de segurança, levando-nos para uma zona proibida de espaços intocáveis de poder. Exibindo a mesma ideia, Stasi City também foi filmado em edifícios abandonados. Uma vez que estes edifícios são o antigo quartel-general da polícia secreta da Alemanha do Leste em Berlim e uma anterior prisão da Stasi, podemos descrever a obra como interrogando sítios de interrogatório. 


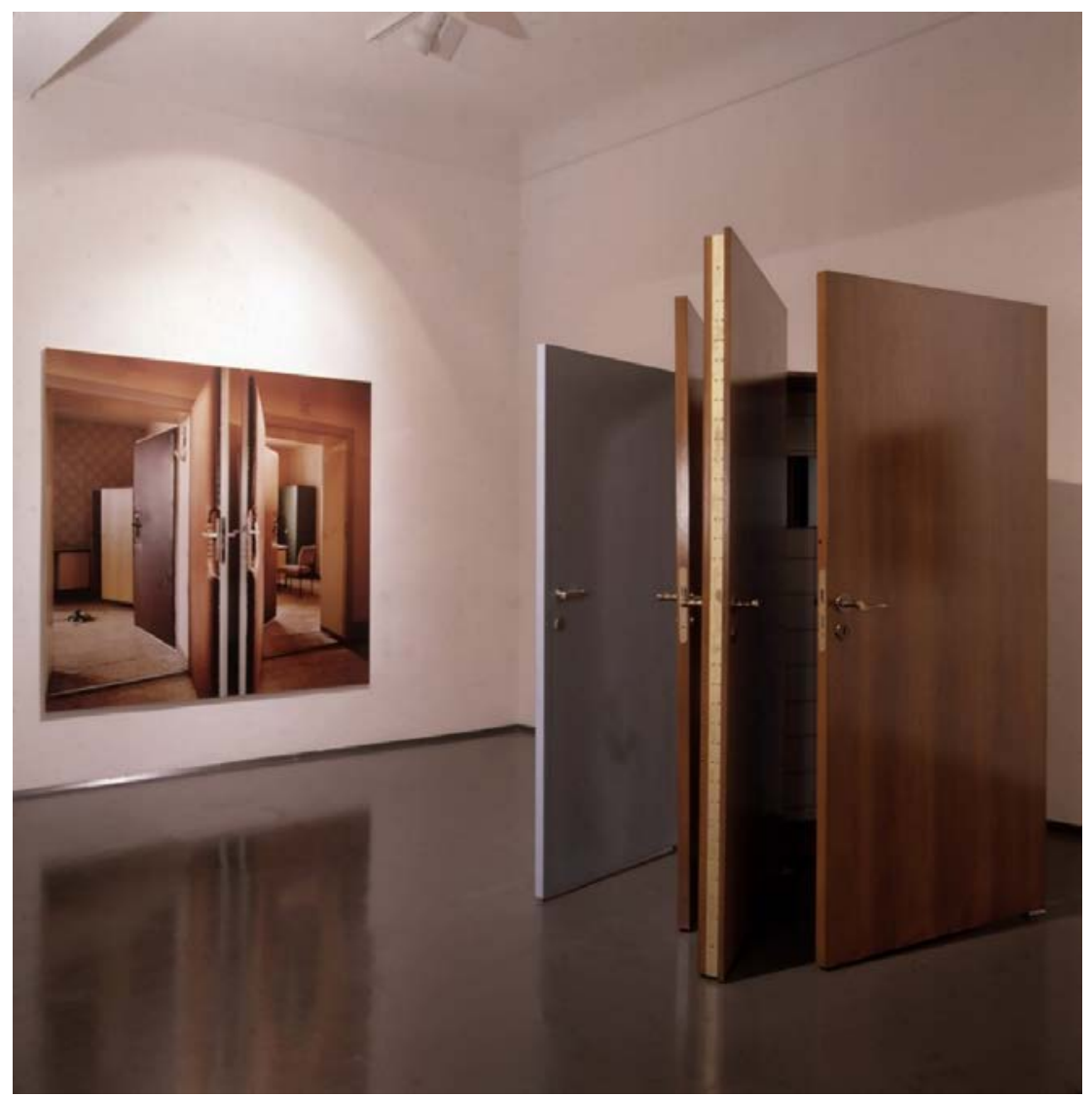

Figura 9: Jane e Louise Wilson, Reconstruction of Doors, Erich Mielke's Office, Former Stasi Headquarter, 1997. Imagem da instalação de Stasi City, 1997, em Grazer Kunstverein, Hannover, 1998. Foto: Steirischer Herbst. Cedida pelas artistas e Galeria Lisson, Londres.

De um modo intenso e subtil, Stasi City parece, tal como outras obras das gémeas, um cenário. $\mathrm{Na}$ verdade, a instalação reconstitui situações que eram elas próprias encenadas de modo a instigar ansiedade e medo. Há figuras enforcadas, talvez evocando um medo mortal de morte por enforcamento. Ou talvez estejam apenas suspensas, sentenças suspensas - suspensas, isto é, no ponto zero de gravidade do moroso tempo burocrático. O espaço é cuidadosamente coreografado. Isento de presença humana, com as portas fechadas que aprisionavam o suspeito, agora escancaradas, é revelada a construção do próprio espaço de medo. Podemos agora ver o caráter barato, inclusive falso, do mecanismo psicológico aqui encenado o mecanismo que gere um teatro do terror.

A técnica de revelar o mecanismo interno de uma arquitetura abandonada é recorrente na obra das irmãs gémeas. Por exemplo, de um modo diferente porém relacionado, as portas abertas do Parlamento britânico em Parliament (1999) também questiona o poder neste sentido, permitindo-nos ter um vislumbre do mecanismo que regula o domínio social quando espreitamos para o sistema de autoridade e legalidade. No entanto, apenas podemos lá estar quando o lugar não está a ser utilizado, justamente porque não está em funcionamento. Jane e Louise Wilson são sempre atraídas para sítios de 
poder e controlo, mas apenas após os responsáveis terem abandonado o lugar. O seu interesse reside em aceder a lugares vazios, desocupados, para explorarem o que ali já não controla nada. Elas gostam de sítios fora de controlo. Ou, melhor, elas estão interessadas no que acontece quando um sítio perde o controlo, quando se perde um sítio.

A este respeito, a obra das Wilson lembra um outro artista da arquitetura, Robert Polidori. Nos seus retratos fotográficos, em particular na sua ideia de Chernobyl e Pripyat, Polidori coloca-se na mesma posição (Polidori 2003). Também ele investiga os restos, representando as ruínas do poder e os efeitos da industrialização igualmente com uma perspetiva arquitetónica. A sua câmara também viaja através de lugares com marcas de destruição. Impregnado pela patine do tempo, nas fotografias de Polidori são mostrados, ou melhor, são postos a nu, lugares abandonados - as suas entranhas à vista de todos. De alguma forma, as suas interpretações de Chernobyl e Pripyat equiparam-se a Home/Office (1998), das Wilson, uma instalação que re-apresenta filmagens antigas dos bombeiros de Londres. Os seus círculos de memória levam-nos para os estragos da destruição, permitindo-nos habitar o que são agora lugares inabitáveis.

\section{Viagens Arqueológicas}

A Free and Anonymous Monument partilha com muitos outros trabalhos que a dupla realizou a forma da meditação sobre questões de abandono, arruinamento pós-industrial e desperdício tecnológico. $\mathrm{Na}$ verdade, estas artistas há muito que mostram uma preferência por instalações visionárias e maquínicas - arquiteturas mentais que são quase paisagens e desertos da mente. Pensemos, por exemplo, o desolado resultado espacial de Proton, Unity, Energy, Blizzard (2000). Quatro ecrãs monitorizam simultaneamente o espaço de um cosmódromo russo, apresentando-nos o mecanismo de produção de uma fábrica de foguetões Proton. Encontramo-nos num hangar abandonado, visitamos escritórios vazios e instalações médicas. Seguimos uma sequência narrativa de telefones que já não tocam. Tentamos decifrar assinaturas - traços de vida - deixadas em portas, agora apenas decorativas, portas que já não abrem nem fecham para ninguém. Camelos habitam o espaço literalmente deserto. À medida que se afastam do que foram torres de lançamento, eles conduzem-nos para fora deste deserto humano. 


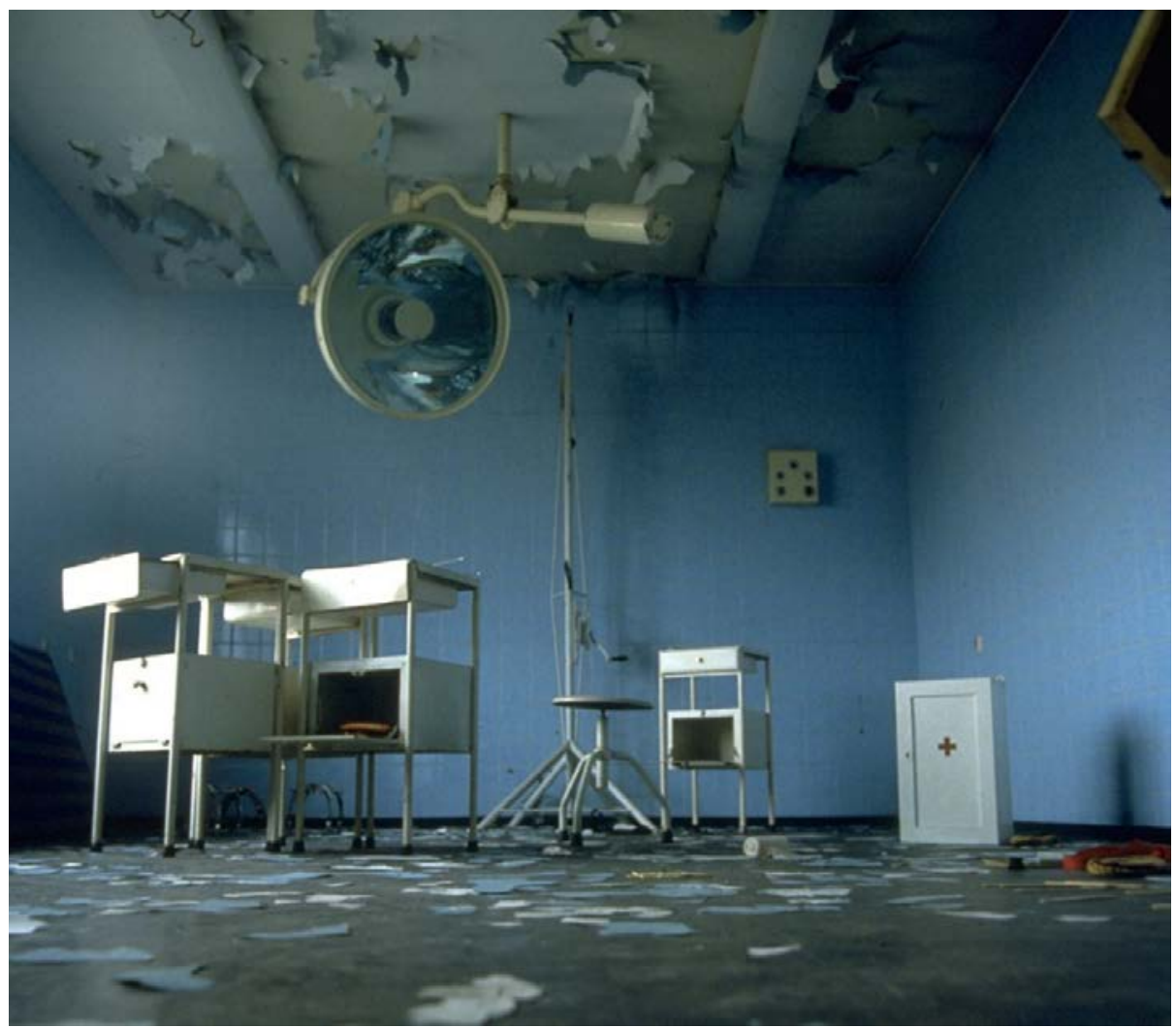

Figura 10: Jane e Louise Wilson, Hospital Room, Hohenschönhausen Prison, 1997. Impressão tipo C em alumínio de Stasi City, 1997. Cedida pelas artistas e Galeria Lisson, Londres.

Na mesma linhagem, Dreamtime (2001) analisa os rituais do lançamento de foguetões e viagens espaciais com uma solenidade militar monumental. Equipara-se a Star City (2000), também dedicado à então futurista, agora antiga, arte de viajar fora do espaço. Nesta cidade perdida, exploramos arquitetonicamente a forma cinética de foguetões e naves espaciais, pois as artistas deixam-nos viajar dentro e fora dos limites do espaço. Mais uma vez, ficamos impressionados pela presença da ausência. Fatos de astronautas vazios, vestiários vazios, cápsulas e escritórios vazios. Fatos e salas esvaziados de uma presença. Neste modo, a astuta e observadora câmara das Wilson liga a arquitetura ao vestuário, comparando-os a espaços do corpo, ambos habitados pela carne. Mostra-nos o que acontece quando os corpos partem e a vida é despejada dos lugares. Com a partida dos habitantes adequados a estes espaços, restam apenas conchas vazias, que melancolicamente vagueiam sem vida no ecrã.

\section{Jardins da Era Pós-industrial}

Jane e Louise Wilson regressam sempre ao que resta de um lugar ao que foi abandonado ou, inclusive, ao que sobrou - e este regresso alarga-se à paisagem industrial que compõe A Free and Anonymous Monument. Virando-se para uma geografia regional marcada pelos problemas da pós-industrialização, a instalação olha para um lugar 
em ruínas. De fato, o estado do pavilhão de Victor Pasmore é ruinoso. Outrora uma estrutura imaculada, um monumento utópico à ideia de encenar a transformação social através do planeamento urbano, o Pavilhão Apollo é agora uma sombra do seu eu inicial. O que vemos ininterruptamente na instalação é uma construção sem manutenção, delapidada, parcialmente desmantelada e inclusive encerrada.

Em julho de 2000, o Sunday Telegraph anunciava com satisfação a possível vitória de uma campanha para demolir o Pavilhão Apollo, apesar do seu estatuto no património inglês como "uma importante obra-prima a nível mundial”. O Telegraph rotulou o Pavilhão Apollo como uma "confusão de betão". Pouco entusiasmado pelo seu material modernista, o jornal noticiava que "as pessoas das redondezas pensam nele como apenas um monte de sujidade, betão viscoso ao qual a juventude sobe para ter relações sexuais e urinar nos outros transeuntes" (Burnham e Harrison 2000). De fato, o espaço tem sido desgastado pelo modo como a população mais jovem usa a solitária estrutura de betão.

Tal parece nunca ter incomodado Victor Pasmore, que morreu em 1998. Quando o artista regressou à região de Newcastle para visitar Peterlee, ele testemunhou a desfiguração dos murais que tinha criado para decorar o pavilhão. Grafitos cobriam a desmoronada fachada desta construção em betão. Não se mostrou perturbado por aquilo que outros viram como um estado de desolação. Pelo contrário, ele considerou o graffiti como uma melhoria. Ele afirmou que esta intervenção tinha melhorado a arquitetura da sua construção, mais do que ele próprio poderia ter feito, e acreditava que este tipo de apropriação tinha humanizado a construção.

Enquanto inscrição cinemática da arquitetura de pavilhão, $A$ Free and Anonymous Monument, de Jane e Louise Wilson, é um grafito metafórico. É ele próprio um ato de apropriação, não apenas do Pavilhão Apollo como matriz artística, mas da totalidade da sua região pós-industrial. É, além disso, uma apropriação pessoal, uma vez que é um ato de amor ao lugar de juventude das artistas. Não é irrelevante que Jane e Louise Wilson tenham nascido em Newcastle, neste centro da exportação de carvão, construção naval e engenharia pesada no século XIX, e que Jane tenha estudado no Politécnico de Newcastle. De algum modo, a estrutura mnemónica do seu monumento é um monumento em movimento em direção ao seu próprio passado e à natureza degradada da paisagem pós-industrial da região.

O pavilhão pós-industrial de Victor Pasmore criou um jardim artificial na zona urbana industrial do noroeste de Inglaterra onde Jane e Louise Wilson cresceram. A sua conceção modernista era uma tentativa utópica de criar recreação onde havia industrialização. O seu gesto reparador dizia respeito a um problema que permanece hoje. A regeneração urbana é agora um problema social e político a um nível global. Enquanto artistas criadas num lugar que enfrentou 
este problema primeiro, as irmãs Wilson são particularmente sensíveis a esta paisagem.

$\mathrm{Na}$ sua arte, Jane e Louise Wilson insistem em pesquisar e em intervir em sítios que têm a textura da sua região e no sítio da própria intervenção urbana de Pasmore. Concluindo a coleção do seu anterior projeto de paisagens lembradas, a sua última aventura é uma obra filmada em Nova Iorque, em Governors Island ${ }^{13}$. Uma ilha ao largo de Manhattan, foi residência não só do governador mas também de instalações da marinha, penitenciárias e militares. Lugar de residência de cerca de cinco mil pessoas que em tempos trabalharam nessas infraestruturas, está agora completamente deserta. Não admira que o maior e mais atrativo lugar de potencial regeneração urbana na região de Nova Iorque tenha atraído as Wilson para outra intervenção fílmica. Encontra-se justamente no seu caminho de criação de uma geografia urbana perdida.

\section{As Nossas Ruínas Modernistas}

No fim de contas, a instalação de A Free and Anonymous Monument expõe o implacável e recorrente fascínio de Jane e Louise Wilson pelas ruínas da modernidade. Apesar da sua abordagem a esta arquitetura mental ser tão pessoal e particular que transpira traços de um regresso psicogeográfico, podemos ver, através do seu trabalho, um interesse pessoal na história ambiental do resultado da industrialização e da Guerra Fria, aquilo que os tornou temas da modernidade artística.

No que diz respeito ao envolvimento concreto com as vicissitudes da arquitetura moderna, o seu ato de redesenharem o projeto de Pasmore lida com um problema específico do desaparecimento da modernidade - as ruínas do modernismo. A este respeito, a sua intervenção junta-se a outras de artistas contemporâneos, para quem o legado do modernismo é uma história atual que temos de enfrentar. De um modo semelhante, Gabriel Orozco, por exemplo, tomou a responsabilidade de reconstruir a então imaculada, mas agora degradada, arquitetura modernista de 1952 de Carlo Scarpa, numa obra apresentada na Bienal de Veneza em 2003.

Mas, o que queremos dizer com uma revisitação pessoal deste legado? Podemos realmente falar de uma ruína modernista? Ao contrário da pedra porosa e permeável das construções antigas, o material do modernismo não se "degrada". O betão não envelhece. Não se desgasta lentamente nem se corrói, não se dissolve nem se desvanece. Não se consegue desintegrar na totalidade. De algum modo, a passagem do tempo não toca a arquitetura modernista. Adversa à deterioração, não envelhece facilmente, graciosamente, ou elegantemente.

\footnotetext{
${ }^{13}$ Trata-se de um projeto Public Art Fund de Nova Iorque.
} 


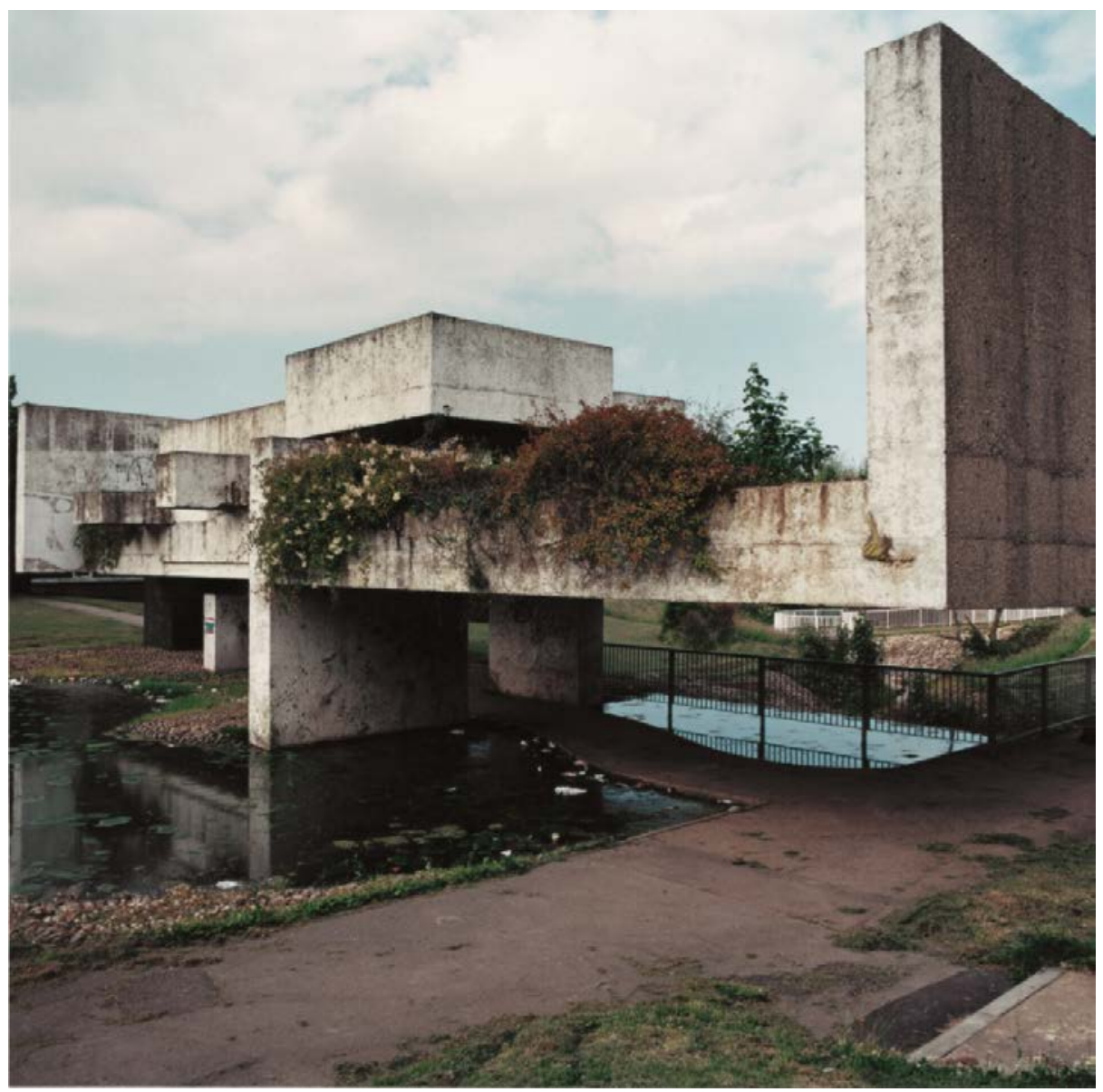

Figura 11: Jane e Louise Wilson, A Free and Anonymous Monument, 2003. Imagem de produção do Pavilhão Apollo de Victor Pasmore, em Peterlee, 1958, para a instalação no BALTIC Centre for Contemporary Art, de 13 de setembro a 30 de novembro de 2003. Cedida pelas artistas e Galeria Lisson, Londres.

O modernismo, afinal de contas, tem um problema com a história. Era uma arte do presente. A arquitetura moderna parece bem no seu próprio presente. Veste-se a si mesma no agora, e não se despe. Brilha quando recentemente construída ou pintada de fresco. Não pode melhorar quando vestida de branco. Veste apenas puros casacos de tinta e modas imaculadas. Parece fantástica quando acabada de fazer. A sua fachada é um rosto que não pode conter marcas de envelhecimento, não gosta de as "vestir". Com o betão não pode mais haver rugas que gentilmente surgem no rosto da construção, rugas que desenham no mapa do tempo passado. Com o betão surgem apenas rachas, a destruição da fachada.

Se a fachada é um rosto, então o problema do modernismo é a pele. A arquitetura modernista era, afinal de contas, um arquitetura da superfície. Esta epiderme moderna tem o mesmo problema com o tempo que nós. Também nós, sujeitos modernos, temos um crescente problema com a deterioração da nossa pele. Recusando envelhecer graciosamente, procuramos o arranjo radical. Uma operação plástica pode ser ela mesmo uma medida, talvez até uma invenção, do tempo modernista e da sua passagem. É um sinal dos tempos. 
Como vivemos uma era que, de tantos modos, afasta a ruína, que tipo de arqueologia podemos nós agora criar? Ao respondermos a esta questão, podemos dar uma última olhadela à arqueologia de Jane e Louise Wilson, e abordar de acordo com mais um ponto de vista o seu fascínio com as ruínas pós-industriais. Devemos compreender que a nossa história é feita de diferentes ruínas. Nos tempos modernos, diferentes arquiteturas transportam a marca do tempo. A passagem do tempo não está simplesmente gravada na superfície de pedra, mas está marcada na superfície de celuloide. Está impressa em outros tipos de arquitetura - os ecrãs translúcidos de instalações de imagem-movimento. As imagens em movimento escrevem a nossa história moderna. Podem ser testemunhos vivos em movimento dos efeitos da duração. As imagens em movimento são as ruínas da modernidade. Elas são os nossos tipos de monumentos. A Free and Anonymous Monument.

Tradução de Susana Viegas e Sérgio Lavos.

\section{BIBLIOGRAFIA}

Baudelaire, Charles. 1993. O pintor da vida moderna, trad. Teresa Cruz. Lisboa: Vega.

Bowness, Alan. 1980. "Introduction," in Victor Pasmore: With a Catalogue Raisonné of Paintings, Constructions and Graphics, 19261979, ed. Alan Bowness and Luigi Lambertini, 9-17. London: Thames and Hudson.

Burnham, Nigel, and David Harrison. 2000. "Sixties 'concrete bungle' sculpture to be scrapped.” The Sunday Telegraph, July 16.

Bruno, Giuliana. 2002. Atlas of Emotion: Journeys in Art, Architecture, and Film. London: Verso.

Corrin, Lisa. 1999. "In Stereoscopic Vision: A dialogue between Jane \& Louise Wilson and Lisa Corrin," in Jane \& Louise Wilson: Stasi City, Gamma, Parliament, Las Vegas, Graveyard Time, ed. Lisa Corrin, 6-15. London: Serpentine Gallery.

Eisenstein, Sergei. 1989. "Montage and Architecture," Assemblage 10: 111-131.

Giedion, Sigfried. 1962. Space, Time and Architecture. Cambridge: Harvard University Press.

-_- 1969. Mechanization Takes Command. New York: Norton.

Kern, Stephen. 1983. The Culture of Time and Space, 1880-1918. Cambridge: Harvard University Press. 
Le Corbusier. 1964. Oeuvre complète, vol. 2. Edited by Willi Boesiger. Zurich: Editions Girsberger.

Lee, Pamela M. 1999. Objects to Be Destroyed: The Work of Gordon Matta-Clark. Cambridge: MIT Press.

Millar, Jeremy e Claire Doherty. 2000. Jane and Louise Wilson. London: Film and Video Umbrella.

Robbins, David, ed. 1990. The Independent Group: Postwar Britain and the Aesthetics of Plenty. Cambridge: MIT Press.

Rieg1, Alois. 1985. Late Roman Art Industry [1901], trans. Rolf Winkes. Rome: Giorgio Bretschneider Editore.

Riegl, Alois. 1993. Problems of Style: Foundations for a History of Ornament [1893], trans. Evelyn Kain. Princeton: Princeton University Press.

Schjeldahl, Peter. 1999. "V.I.: Jane \& Louise Wilson," in Jane \& Louise Wilson: Stasi City, Gamma, Parliament, Las Vegas, Graveyard Time, ed. Lisa Corrin, 4-5. London: Serpentine Gallery.

Polidori, Robert. 2003. Zones of Exclusion: Pripyat and Chernobyl. Göttingen: Steidl. 